\title{
Assessment of Pharmacognostic, Phytochemical and Physicochemical Standards of Aralia racemosa (L.) root
}

\author{
D S N B K Prasanth ${ }^{1}$, Atla Srinivasa Rao², Rajendra Prasad Yejella ${ }^{3}$ \\ 1'Department of Pharmacy, JNTUK, Kakinada, Andhra Pradesh, INDIA. \\ 2Department of Pharmaceutical Analysis and Quality Control, Shri Vishnu College of Pharmacy, Bhimavaram, Andhra Pradesh, INDIA. \\ ${ }^{3}$ Department of Pharmaceutical chemistry, University College of Pharmaceutical Sciences, Visakhapatnam, INDIA.
}

\begin{abstract}
Context: Ethnomedicinally, the root of Aralia racemosa L. (Araliaceae) has long been used in various ailments in traditional system; most importantly it is used against rheumatism, whooping cough, skin diseases, pleurisy, diaphoretic, diuretic, asthma, diarrhoea, syphilis, inflammation and hay fever. The main problem experienced in standardization of herbal drugs is lack of proper identification of plant source. So there is need to establish quality control parameters by using pharmacognostic and phytochemical evaluation, which ensures the purity, safety and efficacy of medicinal plant $A$. racemosa. Aim: To evaluate pharmacognostic properties including macroscopic, microscopic and physicochemical parameters of the root of $A$. racemosa. Methods: Micro and Macroscopic characters of fresh and dried root samples were investigated. Physicochemical parameters were done by utilizing WHO recommended parameters, preliminary phytochemical and fluorescent analysis of root sample were performed for identification and standardization of root of $A$. racemosa. Results: The colour, shape, size, odour and surface characteristics were noted from the root and powdered root material of $A$. racemosa. Light electron microscope images of cross section of root and powdered root revealed that the presence of lignified sclerides, cork cells, lignified spiral vessels, medullary rays and parenchymatous cells. Phytochemical screening showed the presence of tannins, volatile oils, flavonoids, saponins, triterpenes and glycosides. Physicochemical parameters such as moisture content, ash value, extractive value and fluorescent behaviour of root powder were determined. These parameters are useful tools to differentiate the powdered drug material. Conclusion: The present study is helpful to supplement the information with regard to its standardization and identification and in carrying out further research in ayurvedic system of medicine.
\end{abstract}

Key words: Pharmacognostic, Microscopical, Lignified sclerides, Aralia racemosa. L., physicochemical and Lignified spiral vessels.

\section{INTRODUCTION}

The process of standardization is attained by pharmacognostic studies that aid in identification and authentication of a plant material. Proper identification and quality assurance of the raw materials are essential in herbal remedy to insure their quality, efficacy and safety. Pharmacognosy could be an easy and reliable tool, by that complete information of the crude drug is obtained. Most of the pharmacopeias and regulatory guidelines are recommended macroscopic and microscopic analysis and chemical profiling of herbal materials for quality control and standardization. ${ }^{1}$

Aralia racemosa L. (A. racemosa) is commonly known as American Spikenard and belongs
Submission Date : 02-05-2016 Revision Date : :20-06-2016 Accepted Date : 02-07-2016

DOI: 10.5530/ijper.50.3.33 Correspondence: Mr. D S N B K Prasanth, Department of Pharmacy, JNTUK, Kakinada, Andhra Pradesh, INDIA..

Phone- +917382027437 E-mail: dsnbkprasanth@ gmail.com 
to the family Araliaceae. The genus Aralia is comprised of 71 species of plants distributed cross wise over Asia, Mexico, North America, and South America. In 1994, Smith identified the North American species of Araliaceae and recognized the following eight species of Aralia i.e., A. racemosa, $A$. californica, $A$. nudicaulis, $A$. spinosa, $A$. bispida, $A$. bumilis, $A$. regeliana and $A$. scopulorum. Standley recognized five species of Aralia from Mexico: $A$. scopulorum, $A$. regeliana, $A$. bumilis, $A$. pubescens, and $A$. racemosa. The genus is closely related to the genus Panax, which contains Asian and American ginseng (P. ginseng and P. quinquefolius). Several plants in the genus Aralia are used medicinally for various maladies. A. racemosa is indigenous to Canada and the United States southward to the mountains of South Carolina and westward to the Rockies. ${ }^{2}$ It is traditionally used by Indians as carminative, antiseptic, in cough preparations, pain in the breast, mortifications, rheumatism, Whooping cough, skin diseases, pleurisy, diaphoretic, diuretic, pulmonary diseases, asthma, diarrhea, stimulant, expectorant, syphilis, inflammation and hay fever. ${ }^{3,4}$

A. racemosa is an aromatic perennial herb attains a height of 2 to 5 feet. Root large, thick, spicy-aromatic; bark thick, whitish internally as shown in Figure 1. Stem ligneously herbaceous, smooth, bifurcating, much branched and devoid of prickles. Leaves very large, odd pinnately compound; leaflets ovate to cordate, doubly serrate, acuminate, and slightly downy; stipules represented by a serrate stipular membrane at the bifurcation of branches and sometimes at the base of the petiole. Inflorescence numerous axillary, compound, racemose panicles or thyrsi; Flowers monoeciously polygamous. Calyx 5 coherent with the ovary; petals 5 epigynous, obovate, acute, reflexed- spreading, caducous; stamens 5, epigynous, situated opposite to the calyx; filaments slender; anther is 2-celled opening longitudinally. Ovary globular, 5-celled, somewhat 10-ridged; ovules anatropous suspended one in each cell; styles 5 closely clustered, sometimes united at the base; stigmas capitellate. Fruit globular, aromatic, baccate drupes

Phytochemical investigation on Aralia racemosa $\mathrm{L}$. revealed the presence of triterpenoidal saponins i.e., oleanolic acid, sterols i.e., $\beta$-sitosterol and Diterpenoids i.e., ent-Kaurenoic acid, continentalic acid. ${ }^{5,6}$

Various pharmacological activities of Aralia racemosa. $\mathrm{L}$ has been reported such as antioxidant, antidiabetic ${ }^{7,8}$ and antitubercular. ${ }^{9}$ Hence, in this work we make an attempt for standardization of Aralia racemosa L. to study the morphological, anatomical, physicochemical and preliminary phytochemical analysis of root was done.

\section{MATERIAL AND METHODS}

\section{Plant material and Authentication}

Aralia racemosa $\mathrm{L}$. root were procured in the month of September 2015, from Sri Venkateswara University, Andhra Pradesh. It was identified and authenticated by K. Madhavachetty, plant taxonomist, Department of Botany, Sri Venkateswara University, Tirupati, Andhra Pradesh and voucher specimen of the plant (No 1489) was deposited at the herbarium for future reference.

\section{Pharmacognostic evaluation}

\section{Organoleptic evaluation}

Organoleptic characteristics of Aralia racemosa L. root was assessed by observing colour, odour, taste, size and shape according to WHO quality control methods for herbal medicine. ${ }^{10-12}$

\section{Microscopic evaluation}

\section{Preparation of sections}

Free handed sections of the root were cut into thin sections manually with sharp cutting edge of blade. Then transferred on slide, cleared by warming with chloral hydrate, stained with phloroglucinol and Conc. $\mathrm{HCl}$ and mounted in glycerin. The lignified and cellulosic tissues were recognized by utilizing different staining techniques. ${ }^{10}$

\section{Powder microscopy}

The powder microscopy was performed according to the method mentioned in Khandelwal. ${ }^{10}$

\section{Physicochemical Analysis}

Physicochemical parameters such as ash value, moisture content and extractive values were determined according to the procedures mentioned in WHO quality control methods for herbal materials. ${ }^{11}$

\section{Phytochemical Analysis}

Chloroform, methanol and water extracts of Aralia racemosa $\mathrm{L}$. were subjected to qualitative chemical

\begin{tabular}{|c|c|}
\hline $\begin{array}{c}\text { Table 1: Organoleptic characteristics of } \\
\text { Aralia racemosa. L root } \\
\text { Organoleptic characters }\end{array}$ \\
\hline & Observation \\
\hline Colour & Root \\
\hline Odour & Brown \\
\hline Taste & Nomatic \\
\hline Size & 8 to $13 \mathrm{~cm}$ \\
\hline Texture & Rough \\
\hline Fracture & Fibrous \\
\hline
\end{tabular}


Table 2: Physicochemical Parameters of root powder of Aralia racemosa $L$

\begin{tabular}{|c|c|}
\hline Parameters & Values $\% \mathbf{w} / \mathbf{w}$ \\
\hline Moisture content (Loss on drying) & $8 \pm 0.05$ \\
\hline Total ash & $4.26 \pm 0.23$ \\
\hline Acid insoluble ash & $0.12 \pm 0.01$ \\
\hline Water soluble ash & $0.23 \pm 0.02$ \\
\hline Petroleum ether soluble extractive value & $0.8 \pm 0.02$ \\
\hline Chloroform soluble extractive value & $1.6 \pm 0.02$ \\
\hline Ethyl acetate soluble extractive value & $2.4 \pm 0.05$ \\
\hline Alcohol soluble extractive value & $3.6 \pm 0.03$ \\
\hline Water soluble extractive value & $9.8 \pm 0.03$ \\
\hline
\end{tabular}

Table 3: Phytochemical analysis of various extracts of Aralia racemosa L. root

\begin{tabular}{|c|c|c|c|c|}
\hline Phytoconstituents & Method & $\begin{array}{c}\text { Aqueous } \\
\text { Extract }\end{array}$ & $\begin{array}{c}\text { Alcoholic } \\
\text { Extract }\end{array}$ & $\begin{array}{c}\text { Chloroform } \\
\text { Extract }\end{array}$ \\
\hline \multirow[t]{3}{*}{ Flavonoids } & Shinoda Test & + & + & - \\
\hline & Zn. Hydrocholride test & + & + & - \\
\hline & Lead acetate Test & + & + & - \\
\hline Volatile oil & Stain test & - & + & - \\
\hline \multirow[t]{2}{*}{ Alkaloids } & Wagner Test & - & - & - \\
\hline & Hager's Test & - & - & - \\
\hline \multirow[t]{2}{*}{ Tannins \& Phenols } & $\mathrm{Fecl}_{3}$ Test & + & + & + \\
\hline & Potassium dichromate test & + & + & + \\
\hline Saponins & Foaming Test & + & + & - \\
\hline Steroids & Salkowski test & + & + & - \\
\hline Carbohydrates & Molish test & - & - & - \\
\hline Acid compounds & Litmus test & - & - & - \\
\hline Glycoside & Keller-Killani Test & + & + & - \\
\hline Amino acids & Ninhydrin test & - & - & - \\
\hline Proteins & Biuret & - & - & - \\
\hline
\end{tabular}

Table 4: Fluorescence analysis of Aralia racemosa. $L$ root powder

\begin{tabular}{|c|c|c|c|}
\hline \multirow{2}{*}{ Solvent used } & Visible light & \multicolumn{2}{|c|}{ UV light } \\
\cline { 3 - 4 } & & At short (254 nm) & At Long (366 nm) \\
\hline Distilled water & Buff & Buff & Dark Brown \\
\hline $1 \mathrm{~N} \mathrm{NaOH} \mathrm{1N} \mathrm{Methanol}$ & Brownish yellow & Brownish grey & Brownish Black \\
\hline $1 \mathrm{~N} \mathrm{HCl}^{*} \mathrm{HNO}_{3}$ & Pale Brown & Greenish grey & Dark greenish grey \\
\hline $\mathrm{FeCl}_{3}$ & Pale Brown & Greenish grey & Dark greenish grey \\
\hline $\mathrm{CHCl}_{3}$ & Pale green & Yellowish violet & Bluish green \\
\hline $\mathrm{Picric} \mathrm{acid}$ & Pale Brown & Yellowish grey & Dark brown \\
\hline & Brownish yellow & Yellowish green & Pale green \\
\hline
\end{tabular}




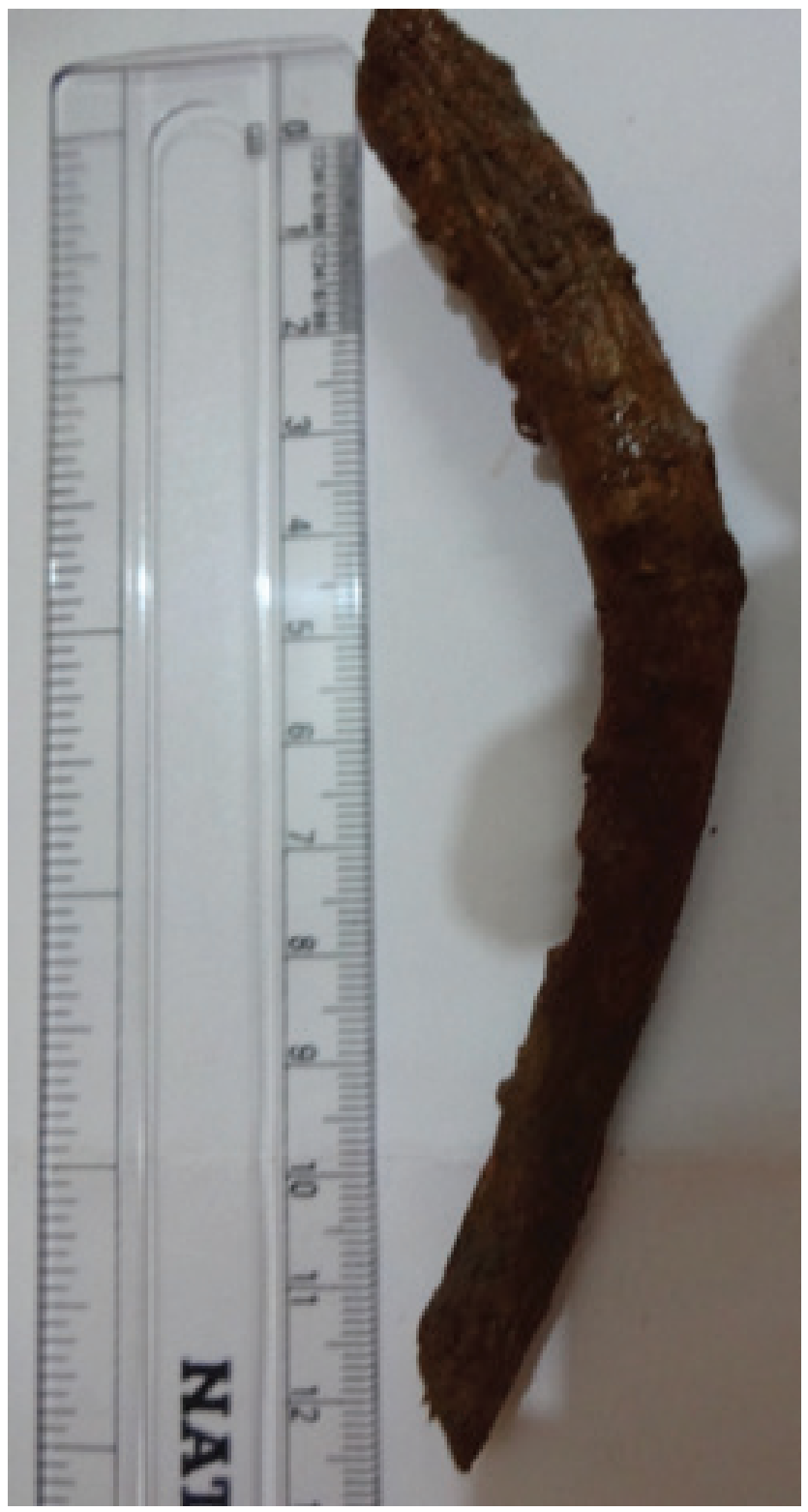

Figure 1: Macroscopic Characteristics of Aralia racemosa. L root.

analysis of various phytoconstituents like alkaloids, glycosides tannins, flavonoids, steroids and volatile oils according to methods of Khandelwal. ${ }^{10,12-14}$

\section{Preparation of extract}

Root of Aralia racemosa were shade dried and powdered. $100 \mathrm{~g}$ of powdered root was subjected to cold maceration by increasing order of polarity viz chloroform, methanol and water. After 24 hrs filtered the extracts and concentrate with the help of rotary evaporator.

\section{Fluorescence analysis of the powdered drug}

The fluorescence examination of the plant material was done by placing the dry powdered root on a slide and observing by treating with a few drops of different chemical reagents to detect the color changes under UV and visible light. ${ }^{10,15}$

\section{RESULTS}

\section{Pharmacognostic evaluation}

\section{Organoleptic and Microscopic evaluation}

The Organoleptic characteristics of root showed in the Table 1 . The transverse section of root of $A$. racemosa L. showed the presence of periderm i.e., 12-16 layered narrow, tangentially elongated cells with dark brown granular matter. Phelloderm is 2-3 layered rows of tangentially elongated thin walled cells. Beneath, there is a presence of lignified scleroidal layer of cells. Cortex was made up of thin walled parenchymatous cells with very small intercellular spaces. The endodermis showed the presence of phloem and xylem. The phloem is present in between the medullary rays. The medullary rays are parenchymatous and are uniserrate to triserate, majorly biserrate. Phloem is well developed and shows the presence of phloem fibres, which are lignified. It also showed the presence of phloem parenchyma. The xylem region was similar to phloem region and was also surrounded by uniserrate to triserrate. Xylem tissue consists of spiral xylem vessels, xylem fibres and xylem parenchyma as shown in Figure 2.

\section{Powder microscopy}

The powder plant material is buff in color, showed pieces of lignified sclerides, lignified spiral vessels, parenchyma, cork cells, medullary rays and Xylem vessels as shown in Figure 3.

\section{Physicochemical evaluation}

The various physicochemical parameters of root and root powder i.e., loss on drying, ash value and extractive value were determined. The total ash, acid insoluble ash, water soluble ash, petroleum ether soluble, chloroform soluble, ethyl acetate soluble, alcohol soluble and water soluble extractive values were $8 \pm 0.05,4.26 \pm 0.23,0.12$ $\pm 0.01,0.23 \pm 0.02,0.8 \pm 0.06,1.6 \pm 0.02,2.4 \pm 0.05$, $3.6 \pm 0.03,9.8 \pm 0.03$ respectively as shown in Table 2 .

\section{Preliminary Phytochemical Screening}

The preliminary phytochemical screening of the extracts viz., chloroform, ethyl acetate, ethanol and water was carried out and the results obtained shown in Table 3.

\section{Fluorescence analysis}

The behavioral changes of powdered drug with distinctive chemical reagents were determined at both UV and Visible light and it is reported as shown in Table 4. 


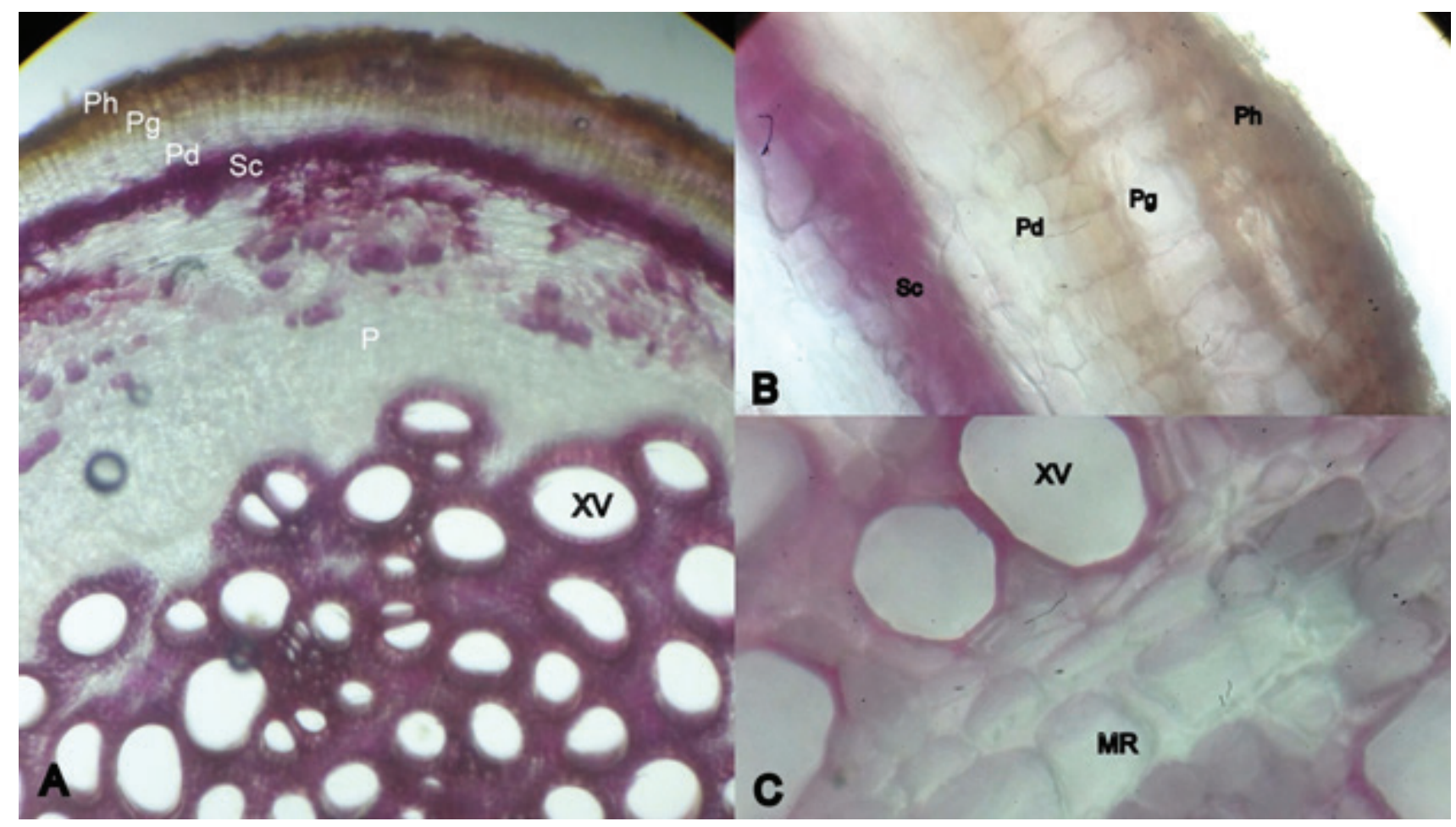

Figure 2: (a) T.S of Aralia racemosa L. root (10X) showed the presence of Phellem (Ph), Phellogen (Pg), Phelloderm (Pd), Scleroidal layer (Sc), Phloem (P) and Xylem Vessels (XV). (b) T. S of A. racemosa L. root showed (40X) showed the presence of Phellem (Ph), Phellogen (Pg), Phelloderm (Pd) and Scleroidal layer (Sc). (c) T.S of Aralia racemosa L. root (40X) showed the presence of Xylem vessels (XV) and medullary Rays (MR).

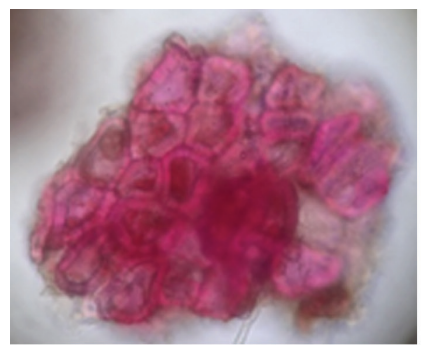

a.Lignified Sclerides

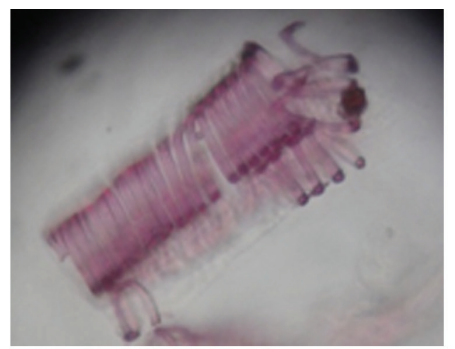

b.Lignified Spiral Vessels

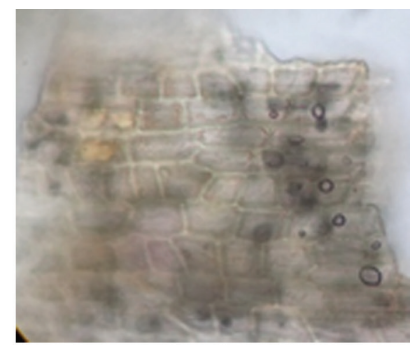

c. Parenchymatous Cells

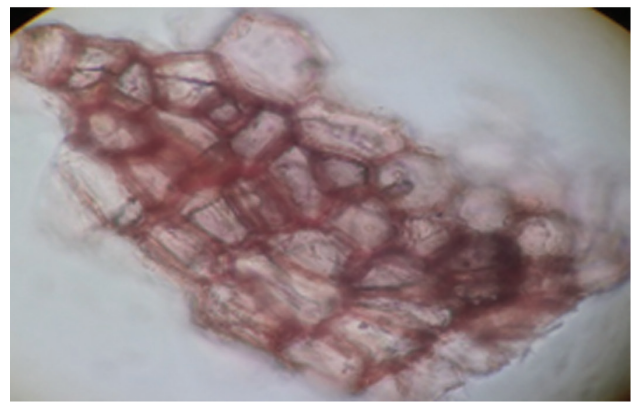

d. Cork Cells

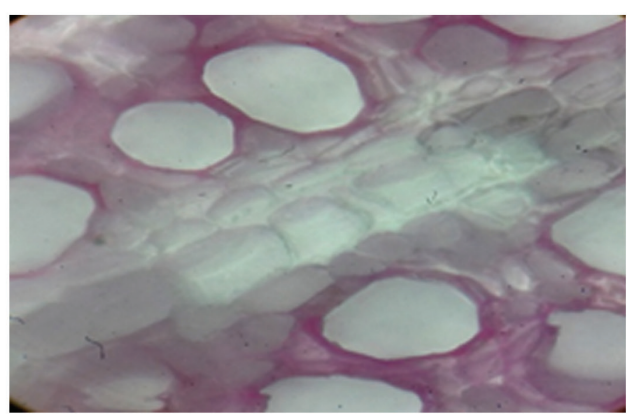

e. Xylem Vessels with medullary rays

Figure 3: Powder microscopy of Aralia racemosa L. root. (a) Lignified sclerides, (b) Lignified spiral vessels, (c) Parenchymatous cells, (d) Cork cells, (e) Xylem vessels with medullary rays. 


\section{DISCUSSION}

To assure reproducible quality of herbal drugs, proper control of starting material is vital. The primary step towards ensuring starting material is authentication. Thus, in recent years there has been rapid increase in the standardization of medicinal plants. Though modern techniques are available, but still identification of medicinal plants is more reliable on pharmacognostic studies. ${ }^{16}$ In this regard, the macroscopic and microscopic features of root have been studied. Macroscopical characters of the root of the plant can serve as a diagnostic parameter. Microscopical study and powder analysis of the plant sample revealed the presence of lignified sclerides, cork cells, lignified spiral vessels, medullary rays and parenchymatous cells. Further this study can also be useful to reduce the possibilities of adulteration of this useful herbal drug when it is available in the powdered form. ${ }^{17}$ Studies of physicochemical parameters can serve as an important source to judge the purity and quality of crude drugs. The extractive values gives the approximate measure of their chemical constituents and from the study, the extractive values of water was highest followed by alcohol. The ash value represents the earthy matter or inorganic components and other impurities present along with herbal drug. The pharmacognostic standard for the root of Aralia racemosa L. laid down for the first time in the study. The phytochemical investigation of different solvent extracts viz., chloroform, methanol and water were examined and it revealed the presence of saponins, tannins, flavonoids, steroids, glycosides and volatile oils.

\section{CONCLUSION}

The data generated from the current study facilitate to authenticate the medicinally important plant $A$. racemosa. Microscopic features could also be useful for establishing the pharmacopeia standards. Morphology as well as various pharmacognostic aspects of root of $A$. racemosa was studied and described along with phytochemical and physicochemical parameters that can be useful in further isolation and purification of medicinally important compounds.

\section{ACKNOWLEDGEMENT}

We extend our sincere thanks to Dr. A. Lakshmana Rao, Principal and management of V. V. Institute of Pharmaceutical Sciences, Gudlavalleru, Andhra Pradesh, for providing the research facilities.

\section{CONFLICT OF INTEREST}

No conflict of interest.

\section{ABBREVIATION USED}

Zn: Zinc; NaOH: Sodium hydroxide; Hcl: Hydrochloric acid; $\mathbf{H N O}_{3}:$ Nitric acid; $\mathbf{F e C l}_{3}:$ Ferric chloride; $\mathrm{CHCl}_{3}$ : Chloroform; UV: Ultraviolet.

\section{REFERENCES}

1. SriramS, SasikumarCG. Pharmacognosticstandardization and physicochemical analysis of the leaves of Barleria montana Wight \& Nees. Asian Pac J Trop Dis. 2016;6(3):232-4. http://dx.doi.org/10.1016/S2222-1808(15)61020-9.

2. Jun W. Systematics and Biogeography of Aralia L. (Araliaceae): Revision of Aralia Sects. Aralia, Humiles, Nanae, and Sciadodendron. United States National Herbarium. 2011;57:1-172.

3. Quattrocchi umberto. CRC World Dictionary of Medicinal and Poisonous Plants: Common names, scientific names, eponyms, synonyms and etymology. London: CRC Press; 2012.

4. Duke JA, Bogenschutz GMJ, duCellier J, Duke pAK. Handbook of Medicinal Herbs, $2^{\text {nd }}$ ed. Raton: CRC press; 2002.

5. Clement JA, Clement Ella SH. The Medicinal Chemistry of Genus Aralia. Curr Top Med Chem. 2014;14(24):2783-801. http://dx.doi.org/10.2174/156802661 5666141208110021

6. Clement JA, Flood MJ, Bleich RM, Willis TJ, Kelly RM, Schmitt JD. Diterpenoids and acetylenic lipids from Aralia racemosa. Biochem Sys Ecol. 2013;51:4-7. http://dx.doi.org/10.1016/j.bse.2013.06.009

7. McCune LM, Johns T. Antioxidant activity in medicinal plants associated with the symptoms of diabetes mellitus used by the Indigenous Peoples of the North American boreal forest. J Ethnopharmacol. 2002;82(2):197-205. http:// dx.doi.org/10.1016/S0378-8741(02)00180-0

8. McCune LM, Johns T. Symptom-Specific Antioxidant Activity of Boreal Diabetes Treatments. Pharm Biol. 2003;41(5):362-70. http://dx.doi. org/10.1076/phbi.41.5.362.15942

9. Grange JM, Davey RW. Detection of antituberculous activity in plant extracts. J appl bacterial. 1990;68(6):587-91. http://dx.doi.org/10.1111/j1365-2672.1990. tb05224.x

10. Khandelwal KR. Practical pharmacognosy techniques and experiments. $19^{\text {th }}$ ed. New Delhi: Nirali Prakashan; 2002. PMCid:PMC137305.

11. Anonymous. Quality Control Methods for Medicinal Plant Materials. Geneva: Office of the Publications, World Health Organization; 1998.

12. Kokate CK. Practical Pharmacognosy. $1^{\text {st }}$ ed. New Delhi: Vallabh Prakashan; 2005.

13. Harborne JB. Phytochemical methods A guide to modern techniques of plant analysis, $2^{\text {nd }}$ ed. USA: Springer; 1984. PMCid:PMC1193218.

14. Raman N. Phytochemical Techniques. New Delhi: New India Publishing Agency; 2006.

15. Patil PS, Venkatanarayanan R, Argade PD, Shinde PR. Assessment of pharmacognostic and phytochemical standards of Thespesia populnea (L.) root. Asian Pac J Trop Biomed. 2012;2(3):S1212-S6. http://dx.doi. org/10.1016/S2221-1691(12)60387-6.

16. Gagan S, Amit C, Uttam SB, Sandeep R, Prabh SS, Ravi KD. Pharmacognostic standardization of leaves of Melaleuca leucadendron. Phcog J. 2013;5(4):143-8. http://dx.doi.org/10.1016/j phcgj2013.07.008.

17. Fiaz A, Qazi Najum us S. Pharmacognostic standardization and preliminary phytochemical studies of Gaultheria trichophylla. Pharm Biol. 2015;53(12): 1711-8. http://dx.doi.org/10.3109/13880209.2014.1003355;PMid:25865038. 


\section{PICTORIAL ABSTRACT}

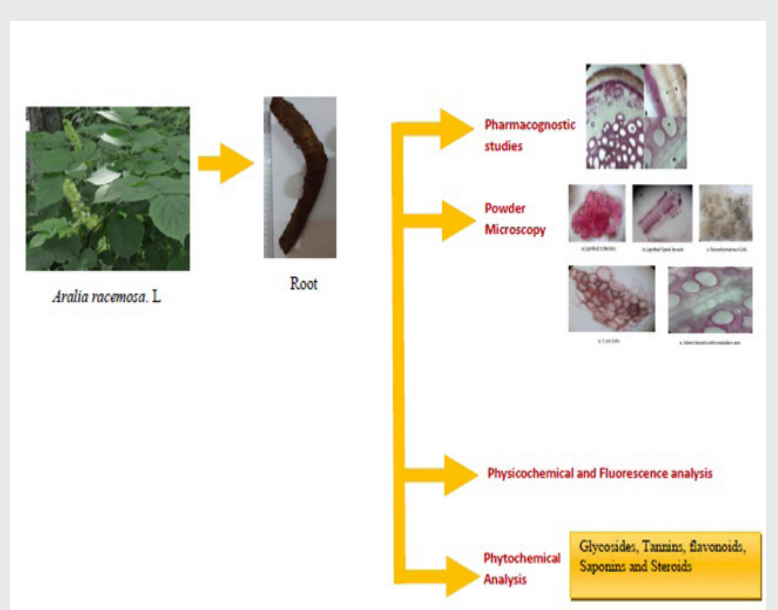

\section{SUMMARY}

- Root of Aralia racemosa L. was procured from Sri Venkateswara University, tirupati and authenticated by Dr. K. Madhavachetty, plant taxonomist.

- The microscopical evaluation showed the presence of lignified sclerides, lignified spiral vessels, parenchyma, cork cells, medullary rays and Xylem vessels

- The physicochemical parameters viz., moisture content, extractive values and ash content were assessed, which are helpful for standardization of the crude drug.

- The preliminary phytochemical screening of successive solvent extraction of root of Aralia racemosa. $\mathrm{L}$ showed the presence of saponins, tannins, flavonoids, steroids, glycosides and volatile oils, which can play a vital role in medicine. 